gram-negative bacteremia traced to contaminated O-rings in reprocessed dialyzers. Ann Intern Med 1993;119:1072-1078.

9. Welbel SF, Schoendorf K, Bland LA, et al. An outbreak of gram-negative bloodstream infections in chronic hemodialysis patients. Am J Nephrol 1995;15:1-4.

10. Humar A, Oxley C, Sample ML, Garber G. Elimination of an outbreak of gram-negative bacteremia in a hemodialysis unit. Am I Infect Control 1996;24:359-363.

11. Longfield RN, Wortham WG, Fletcher LL, Nauscheutz WF. Clustered bacteremias in a hemodialysis unit: cross-contamination of blood tubing from ultrafiltrate waste. Infect Control Hosp Epidemiol 1992;13:160-164.

12. American Public Health Association. 9215 Heterotrophic plate count. In: Eaton $\mathrm{AD}$, Clesceri IS, Greenberg $\mathrm{AE}$, eds. Standard Methods for the Analysis of Water and Wastewater. 19th ed. Washington, DC: APHA; 1995:9-31-8.

13. Bond WW, Hedrick ER. Microbiological culturing of environmental and medical-device surfaces. In: Isenberg HD, Gilchrist MJR, eds. Clinical Microbiology Procedures Handbook. Washington, DC: American Society for Microbiology; 1992:11.10.1-11.10.9.

14. Bland LA. Microbiological and endotoxin assays of hemodialysis fluids Adv Ren Replace Ther 1995;2:70-79.

15. Association for the Advancement of Medical Instrumentation. American National Standard Hemodialysis Systems. ANSI/AAMI RD5-1993. Arlington, VA: AAMI; 1993.

16. Maslow JN, Slutsky AM, Arbeit RD. Application of pulsed-field gel electrophoresis to molecular epidemiology. In: Persing DH, Smith TF, Tenover FC, White TJ, eds. Diagnostic Molecular Microbiology.
Principles and Applications. Washington, DC: American Society for Microbiology; 1993:563-572.

17. Tenover FC, Arbeit RD, Goering RV, the Molecular Typing Working Group of the Society for Healthcare Epidemiology of America. How to select and interpret molecular strain typing methods for epidemiological studies of bacterial infections: a review for healthcare epidemiologists. Infect Control Hosp Epidemiol 1997;18:426-439.

18. Swartz RD, Messana JM, Boyer CJ, Lunde NM, Weitzel WF, Hartman TL. Successful use of cuffed central venous hemodialysis catheters inserted percutaneously. J Am Soc Nephrol 1994;4:1719-1725.

19. Tokars JI, Miller ER, Alter MJ, Arduino MJ. National surveillance of dialysis-associated diseases in the United States, 1995. ASAIO Journal 1998;44:98-107.

20. Jochimsen EM, Frenette C, Delorme M, et al. A cluster of bloodstream infections and pyrogenic reactions among hemodialysis patients traced to dialysis machine waste-handling option units. Am J Nephrol 1998;18:485-489.

21. Centers for Disease Control and Prevention. Outbreaks of gram-negative bacterial bloodstream infections traced to probable contamination of hemodialysis machines-Canada, 1995; United States, 1997; and Israel, 1997. MMWR 1998:47:55-59.

22. Arnow PM, Garcia-Houchins S, Neagle MB, Bova JL, Dillon JJ, Chou T. An outbreak of bloodstream infections arising from hemodialysis equipment. J Infect Dis 1998;178:783-791.

23. Olver WJ, Webster C, Clements H, Weston V, Boswell T. Two cases of Enterococcus faecalis bacteremia associated with a hemodialysis machine. J Infect Dis 1999;179:1312.

\title{
Alcohol Gel as an Antimicrobial Sanitizing Agent
}

\section{Gina Pugliese, RN, MS Martin S. Favero, PhD}

Paulson et al have reported on a study on the antimicrobial efficacy and irritation potential of five handwash product regimens: a nonantimicrobial lotion soap, an antimicrobial lotion soap, an alcohol gel sanitizer, a nonantimicrobial lotion soap with an alcohol gel sanitizer, and an antimicrobial lotion soap with an alcohol gel sanitiz- er. The regimens were evaluated by using a Healthcare Personnel Handwash procedure, and irritation was assessed by using expert hand evaluation after 25 consecutive washes.

The Healthcare Personnel Handwash data showed that the mean log reductions from baseline were greatest for the lotion soaps with alcohol gel sanitizer, less for the alcohol and the antimicrobial soap alone, and least for the bland soap. All of the prod- uct regimens showed a low potential for skin irritation. In terms of both microorganism reduction and skin irritation, the most effective product regimens were the use of alcohol gel sanitizer in combination with either an antimicrobial or a plain lotion soap.

FROM: Paulson DS, Fendler EJ, Dolan MJ, Williams RA. A close look at alcohol gel as an antimicrobial sanitizing agent. Am J Infect Control 1999;27: 332-338.

\section{Sterilization of HIV With Irradiation: Relevance to Infected Bone Allografts}

Campbell and Li from the Royal Adelaide Hospital and Institute of Medical and Veterinary Science, Australia, have challenged the use of radiation bone from HIV-infected individuals. Bone allograft banks commonly sterilize frozen bone by irradiation. The dose-response relationship for HIV is calculated, and the dose required to inactivate the bioburden of virus that may be present in allograft bone is determined. They report on a study where a virus-titre experiment was performed using irradiated frozen HIV. The virus was maintained on dry ice (approximately $-70^{\circ} \mathrm{C}$ ) and was exposed to a cobalt 60 source with $0-40$ $\mathrm{kGy}$ irradiation at $5 \mathrm{kGy}$ intervals. Lymphocyte cell cultures were exposed to serial dilutions of the irradiated virus. The virus titer was quantified by cytological changes of HIV infection and p24 immunofluorescence.

There was a linear relationship between the virus titer and the radiation dose delivered. The inactivation rate of irradiated virus was $0.1134 \log _{10}$ tissue-culture infective doses $50 / \mathrm{mL}$ per $\mathrm{kGy}(95 \%$ confidence intervals, $0.1248-0.1020$ ). The irradiation dose required to inactivate the HIV bioburden in allograft bone is $35 \mathrm{kGy}$. The irradiation dose required to achieve a sterility assurance level of $10-6$ is 89 kGy. This dose exceeds current recommendations for sterilizing medical products and the current practice of many bone banks. The authors concluded that gamma irradiation should be disregarded as a significant virus inactivation method for bone allografts. FROM: Campbell DG, Li P. Sterilization of HIV with irradiation: relevance to infected bone allografts. Aust N Z J Surg 1999;69:517-521. 